\title{
EFFECTS OF AMBIENT TEMPERATURE ON BROILERS PHYSIOLOGY. PERFORMANCE AND MEAT QUALITY
}

\author{
Qiao Yingying \\ Sumy National Agricultural University of Ukraine \\ Henan Institute of Science and Technology of China \\ ORCID: 0000-0002-6202-4935 \\ E-mail:623001806@qq.com \\ Oleksandr Kyselov \\ Sumy National Agricultural University of Ukraine \\ ORCID: 0000-0003-0120-0656 \\ E-mail: kyselov_snau@ukr.net

\section{Liu Changzhong} \\ Henan Institute of Science and Technology of China \\ ORCID: 0000-0001-5219-1089 \\ E-mail:15103733474@163.com
}

The freeding environment has become the most important factor restricting the production efficiency of livestock and poultry. At the same time, the community demand more animal protein is increasing every year. The answer to this question can be the broiler meat. But the intensive production of broiler meat puts increased demands on both growing technologies and conditions of their keeping. The purpose of our research is to study various environmental parameters that may have different effects on poultry growth and health, among which temperature is one of the main factors affecting poultry meat quality. Studies have shown that cold stress leads to a significant increase in CRH mRNA levels, a significant decrease in TRH mRNA levels, and a decrease in the body's antioxidant status. Cold stress causes edema, congestion, hemorrhage and epithelial damage in the intestinal mucosa of broilers, which significantly increases the incidence and severity of poultry necrotizing enteritis lesions $(P<0.05)$, causing $\mathrm{pH}$ and cavitation in the cecum Clostridium counts increased significantly $(P<0.05)$. The heat is also stress, after the occurrence of heat stress, the plasma creatine kinase activity and uric acid concentration of broilers increased, blood volume and oxygen carrying capacity of chickens changed, and hematocrit increased. Studies have shown that the long-term relatively low temperature environment reduces the contents of SFA, PUFA, MUFA, and EFA in the breast muscles of broilers, thereby reducing the flavour and meat quality of broiler breast muscles. Heat stress significantly increased the malondialdehyde (MDA) content in the pectoral muscle tissue $(P<0.05)$, and the selenium content was significantly reduced $(P<0.05)$. Heat stress can also lead to pale and exudative meat characteristics of chicken, namely PSE meat. Ambient temperature stress can lead to reduced feed consumption, indigestion, impaired metabolism, decreased immunity, and even death of broilers. Accordingly on this article we are summarizes the effects of cold and heat stress on physiology, performance and meat quality of broilers, with a view to improve the quality of chicken, maximize the production performance of broilers, increase the economic benefits of farms, and provide theoretical references for the healthy freeding of broilers.

Key words: boriler, ambiernt temperature, physiology, performance, meat quality.

DOI: https://doi.org/10.32845/bsnau.lvst.2019.1-2.5

Broiler breeding has now become one of the more market-oriented, intensive, and large-scale industries in China's animal husbandry [1], and the breeding environment has also become a major issue affecting the health and production performance of broilers, of which environmental temperature is the primary environment One of the factors [2]. Therefore, in the modern large-scale broiler breeding process, attention must be paid to the regulation of the breeding environment temperature.

The thermal neutral zone of broilers is between 16 to 28 . In this temperature range, broilers can maintain maximum productivity, and maintenance needs and basal metabolism to a minimum. Once the outside temperature is below the minimum limit zone, broilers are subject to cold stress. The body will initiate thermoregulation or chemical thermoregulation to maintain body temperature and heat production [3]. When the outside temperature exceeds the upper limit of the body temperature of the poultry, the broiler is subjected to heat stress, and the body dissipates heat through conduction, convection, radiation and evaporation. Many studies have shown that the external ambient temperature exceeds the critical temperature of

broiler body temperature, that is, when the broiler is subjected to cold and heat stress, it adversely affects its physiological functions, production performance, meat quality and health.

1. Influence of ambient temperature on physiological functions of broilers

1.1 Effect of cold stress on physiological functions of broilers

Cold is a kind of stressor. Cold stress is also a kind of stress response. It is controlled by the complex structure of the organism and can cause many abnormal reactions in the body after it occurs [4]. Studies have shown that cold stress leads to a significant increase in CRH mRNA levels, a significant decrease in TRH mRNA levels, and a decrease in the body's antioxidant status [5]. Cold stress can change the utilization or synthesis of ascorbic acid in broilers [6], and can also cause various neuroendocrine, physiological and immune responses to change [7]. Cold stress caused edema, congestion, hemorrhage and epithelial damage in the intestinal mucosa of broilers [8], which significantly increased the incidence and severity of poultry necrotizing enteritis lesions $(P<0.05)$, causing $\mathrm{pH}$ and 
cavitation in the cecum Clostridium counts increased significantly $(P<0.05)[9]$. Some experiments have proven that the ambient temperature is maintained at $32^{\circ} \mathrm{Cand} 30^{\circ} \mathrm{C}$ in the first and second weeks, and then reduced to $15^{\circ} \mathrm{C}$ in the third week. As a result, the incidence of broiler ascites syndrome has increased significantly [10]. broilers

1.2 Effects of heat stress on physiological functions of

High temperature is also a type of stressor. Heat stress affects the physiological characteristics of broilers and induces a variety of physiological disorders, including systemic immune disorders, endocrine disorders and electrolyte imbalances [11]. After the occurrence of heat stress, the plasma creatine kinase activity and uric acid concentration of broilers increased [12], blood volume and oxygen carrying capacity of chickens changed, and hematocrit increased [13]. Heat stress can disrupt the normal endocrine status of the hypothalamus-pituitary-ovary axis, leading to abnormal sexual steroid patterns and impaired reproductive capacity [14], which adversely affects chicken oogenesis, oocyte maturation, fertilization and embryo development It also affects egg production performance and damages spermatogenesis, leading to a decrease in sperm count, motility and fertility rate. The quality of male semen and the fertility of TCCs decreased significantly with the hot season [13] Studies have shown that heat stress causes a decrease in the weight of the bursa and spleen, and a decrease in lymphocyte levels and macrophage activity in the blood [15]. In addition, heat stress can affect immune response by changing the expression of cytokines, making immune cells more susceptible to oxidative stress.

2 Effect of ambient temperature on broiler performance

2.1 Effect of cold stress on broiler performance

Cold can seriously affect the health and reproduction of poultry. This is one of the main causes of bird migration [16]. The energy consumed by broilers is first used to maintain body temperature, and then used for production. When broilers are under low temperature conditions, the part of energy that was originally used for production to maintain normal body temperature is also used to maintain body temperature, which results in feed intake. Increased, as well as increased basal metabolic rate and decreased energy reserve. Studies have shown that the meat ratio of broilers raised in the environment of $10^{\circ} \mathrm{C}$ to $20^{\circ} \mathrm{C}$ is increased by $30 \%$ [17]. Cold stress caused broiler body size or broiler uniformity to be out of standard, which affected production performance [18] and led to severe economic losses [19].

\subsection{Effect of heat stress on broiler performance}

Broilers are generally more sensitive to ambient temperature than other livestock. When the outside temperature reaches 41 , it becomes more and more difficult for the poultry to dissipate excess heat, which will lead to death in severe cases. Modern fast-growing broilers must consume a large amount of feed to obtain the maximum growth rate. However, the intake and metabolism of feed have a thermogenic effect. At high ambient temperatures, the increase in heat generation will be fed back by the heat stress system. Unless the basal metabolic rate can be reduced, poultry will continue to increase heat and feed intake must be reduced to maintain a normal body temperature. As a result, poultry will reduce additional heat production by reducing feed intake. This has a negative impact on its productivity [20]. Because the intestine is the tissue most susceptible to heat stress [21]. Many studies have shown that heat stress results in reduced digestion efficiency, reduced feed-toweight ratio $(F / G)$, reduced metabolic rate, and intestinal microbial imbalances and increased mortality [22]. Acute thermal stress resulted in a $22 \%$ and $5 \%$ reduction in fresh jejunum weight and length, and reduced intestinal villi height [23]. And prone to respiratory alkalosis, which slows growth. Due to reduced feed intake, and often lead to insufficient nutrient intake, eventually leading to reduced production performance [24].

3. Influence of ambient temperature on the quality of broiler meat

\subsection{Effect of cold stress on chicken quality}

Tests have shown that the low temperature environment leads to a significant decrease in subcutaneous fat in broilers. And can change the body's antioxidant function to induce oxidative stress, leading to an increase in free radicals in the volume, causing damage to the body and causing a decline in meat quality [25]. Fatty acids are important chemical substances that make up fat, and also an important factor influencing meat flavor. Among them, PUFA is an important precursor of meat flavor and an indispensable nutrient for the human body. Studies have shown that the long-term relatively low temperature environment reduces the contents of SFA, PUFA, MUFA, and EFA in the breast muscles of broilers, thereby reducing the flavour and meat quality of broiler breast muscles [26].

3.2 Effect of heat stress on chicken quality

Heat stress significantly increased the malondialdehyde (MDA) content in the pectoral muscle tissue $(P<0.05)$, and the selenium content was significantly reduced $(P<0.05)$. Therefore, heat stress can easily induce oxidative damage in broilers [22]. Oxidative damage stress can lead to lipid peroxidation of proteins and oxidative damage to DNA, which can affect the flavor of chicken. High ambient temperature is also an important factor affecting the fat deposition of poultry. In addition, the integrity of the breast muscle of broilers subjected to heat stress is also considered to be related to changes in redox balance, because skeletal muscle of broilers exposed to acute heat stress acts as lipid The indicator of oxidation showed a more than two-fold increase in malondialdehyde (MDA) [27]. Heat stress can also lead to pale and exudative meat characteristics of chicken, namely PSE meat [28]. The Japanese investigation found that the frequency of PSE meat changes with seasons was $32.4 \%, 46.0 \%, 41.3 \%$, and $26.4 \%$. A survey in South Korea found that the incidence of PSE meat in July-September was significantly higher than in other months. High temperature environments significantly increase drip and cooking losses in chicken breast and leg [29]. Lipid peroxidation caused by high temperature environment is the main reason for affecting meat quality [30].

\section{Outlook}

The modern breeding level and intensive breeding model make broiler chickens more and more resistant to stress and become more and more dependent on the microclimate environment in the house. Therefore, study the changes in environmental temperature, that is, the effects of relatively high and low temperatures on broilers in the long term, the effects of relatively high and low temperatures on broilers in the short term, and the effects of intermittent high and low temperatures on broilers, and explore its mechanism from the perspective of molecular biology. And the corresponding nutritional control measures to 
reduce the harm of cold and heat stress to broiler chickens will be the research topics of broiler feeding and nutritional control in

a certain period of time.

\section{References:}

1. Zheng Maiqing, Zhao Guiping, Li Peng, et al. Investigation and analysis of the current status of large-scale development of broiler breeding in China [J]. China National Poultry. 2014, (16): 2-7.

2. Zhong Xiang, Li Gang, Xu Shenglin, et al. Effects of chicken house environmental factors on the health and growth of laying hens [J]. Animal Husbandry and Veterinary Medicine. 2013, (3): 101-103.

3. Huang Yankun, Wang Wenjing, Chen Lidun, et al. Heat regulation mechanism of caged laying hens under high temperature conditions [J]. Contemporary Animal Husbandry. 2002, (3): 7-8.

4. Dawson, W. R, Marsh R. L, Yacoe M. E. Metabolic adjustments of small passerine birds for migration and cold [J]. American Journal of Physiology, 1983, 245 (6):755-67.

5. Parmentier H K. Effect of duration of cold stress on plasma adrenal and thyroid hormone levels and immune responses in chicken lines divergently selected for antibody responses [J]. Poult Sci ,2004, 83 (10):1644-1649

6. Hangalapura B.N., Kaiser M. G., Poel J. J. V. D., et al. Cold stress equally enhances in vivo pro-inflammatory cytokine gene expression in chicken lines divergently selected for antibody responses [J]. Dev Comp Immunol, 2006, 30 (5):503-511.

7. Hangalapura B.N., Nieuwland M. G., De V. R. G., et al. Effects of cold stress on immune responses and body weight of chicken lines divergently selected for antibody responses to sheep red blood cells [J].Poultry Science, 2003, 82 (11):1692.

8.Wang Qijun. Effects of high temperature environment on fat deposition and lipid metabolism of Beijing chicken during different growth stages [D]. Xianyang: Northwest A \& F University, 2006.

9. Tsiouris V., Georgopoulou I., Batzios C., et al. The effect of cold stress on the pathogenesis of necrotic enteritis in broiler chicks [J].Avian Pathology, 2015, 44(6):430-435.

10. Cao Wenbin, Ren Hongchun, Liu Ruifen, et al. Effect of different environmental temperature on carcass quality of broilers [J]. Contemporary Animal Husbandry. 2006, (5): 37-38.

11. Yalm S., Ozkan S., Cabuk M., et al. Pre- and postnatal conditioning induced thermotolerance on body weight, physiological responses and relative asymmetry of broilers originating from young and old breeder flocks [J]. Poult Sci, 2005, 84 (6):967-976.

12. Yang L., Tan G.Y., Fu Y.Q.,et al. Effects of acute heat stress and subsequent stress removal on function of hepatic mitochondrial respiration, ROS production and lipid peroxidation in broiler chickens [J]. Comp Biochem Physiol C, 2010, 151:204-208.

13. Cheng C.Y., Tu W.L., Wang S. H., et al. Annotation of Differential Gene Expression in Small Yellow Follicles of a BroilerType Strain of Taiwan Country Chickens in Response to Acute Heat Stress [J]. Plos One, 2015,10 (11):e0143418.

14. Quinteiro-Filho W.M., Ribeiro A., Ferraz-de-Paula V., et al. Heat stress impairs performance parameters, induces intestinal injury, and decreases macrophage activity in broiler chickens [J]. Poult Sci, 2010, 89:1905-1914 . $2006,1: 15$

15. Hietbrink F., Koenderman L., Rijkers G., et al. Trauma: The role of the innate immune system [J].World J Emerg Surg,

16. Druyan S., Hadad Y., Cahaner A. Growth rate of ascites-resistant versus ascites-susceptible broilers in commercial and experimental lines[J]. Poult Sci, 2008, 87 (5):904-911.

17. Li Rulan. Effects of Cold Stress on Chickens and Control Measures [J]. Poultry Science. 2009, (2): 48-50.

18. Wang Jintao, Sang Xuebo, Diao Caixia, et al.Effect of cold stress on energy metabolism of animal body [J] .Modern Agriculture. 2011, (8): 38-39.

19. Taché Y., Martinez V., Million M., et al. Stress and the gastrointestinal tract III. Stress-related alterations of gut motor function: role of brain corticotropin-releasing factor receptors [J]. American Journal of Physiology Gastrointestinal \& Liver Physiology, 2001, 280 (2): 173-178.

20. Donkoh A., Atuahene C.C. Management of environmental temperature and rations for poultry production in the hot and humid tropics [J]. Int J Biometeorol, 1988, 32 (4): 247-253.

21. Zuo J., Xu M., Abdullahi Y.A., et al. Constant heat stress reduces skeletal muscle protein deposition in broilers [J]. J Sci Food Agric, 2015, 95 (2):429-436.

22. Santos R. R., Awati A., Pj R.D.H., et al. Quantitative histo-morphometric analysis of heat-stress-related damage in the small intestines of broiler chickens [J].Avian Pathology, 2015, 44(1):19-22.

23. Sohail M.U., ljaz A., Yousaf M.S., et al. Alleviation of cyclic heat stress in broilers by dietary supplementation of mannanoligosaccharide and Lactobacillus-based probiotic: dynamics of cortisol, thyroid hormones, cholesterol, C-reactive protein, and humoral immunity [J]. Poult Sci, 2010, 89 (9):1934-1938.

24. Elphick D.A., MahidaY. R. Paneth cells: Their role in innate immunity and inflammatory disease [J]. Gut, 2005, 54:18021809.

25. Su Yingying. Effects of intermittent cold stimulation on broiler performance, meat quality, immunity and antioxidant function [D]. Harbin: Northeast Agricultural University, 2014.

26. Wang Mingyuan. Study on slaughter performance and meat quality of Yunnan yellow cattle under feeding conditions of silage banana stems and leaves [D]. Kunming: Yunnan Agricultural University, 2015.

27. Sayed M.A., Downing J. Effects of dietary electrolyte balance and addition of electrolyte-betaine supplements in feed or water on performance, acid-base balance and water retention in heat-stressed broilers [J]. British Poultry Science, 2015,56 (2):195.

28. Han Ruili, Zhao Xiaofang. Environmental factors affecting chicken quality [J]. China Poultry Industry Guide. 2002, (6): 3435.

Вісник Сумського національного аграрного університету 
29. Duan Hongchuan, Li Zhongping. Factors affecting chicken meat quality and improvement measures [J]. Feed Expo. 2006, (1): 31-33.

30. Li Shaoyu. Effect of heat stress on broiler performance and product quality and anti-stress effect of riboflavin [D]. Beijing: Chinese Academy of Agricultural Sciences, 1999.

\section{Цзао Іньінь}

Кисельов. О.Б.

Лю.Чанчжун

\section{Вплив температури навколишнього середовища на фізіологію бройлерів. Оцінка якості м'яса}

Температурний режим годівлі стає важливим обмежуючим фактором, що впливає на ефрективність виробниитва у тваринництві та птахівництві. Разом з тим потреба населення у білку тваринного походження зростає з кожним роком. Вирішенням цього питання може бути виробництво м'яса бройлерів. Але інтенсивне виробництво м'яса бройлерів висуває підвищені вимоги, як до технологій вирощування, так і до умов їх утримання. Метою наших досліджень є вивчення різних параметрів навколишнього середовища, які можуть по-різному впливати на ріст та здоров'я птиці, серед яких температура - $є$ одним з основних фракторів, що впливає на якість м'яса птиці. Дослідження показали, що холодовий стрес призводить до значного підвищення рівня CRH mRNA та сутmєвого зниження рівня TRH mRNA, а також до зниження рівня антиоксидантів в організмі. Крім того холодовий стрес спричиняє набряки, скупчення, крововиливи та пошкодження епітелію на слизовій оболонці кишківника бройлерів, що значно збільшує частоту захворюваності та схильність до ураження некротизуючого ентериту у птахів $(P<0,05)$, зміну рH та кавітацію сліпої кишки $(P \leq 0,05)$. Tenло також є стресом, наслібками теплового стресу є активність креатинкінази в плазмі крові та зростання концентрація сечової кислоти, змінюється об'єм крові $і$, як наслідок, швидкість транспортування кисню. Дослідження показали, що тривалий вплив низькотемпературного середовища зменшує вміст SFA, PUFA, MUFA, та EFA у грудних м'язах бройлерів, тим самим погіршуючи смак та якість м'яса. Тепловий стрес значно збільшує вміст малодіальдегіду (MDA) у м'язовій тканині грудної клітини ( $P<0,05)$, а вміст селену значно зменшується $(P<0,05)$. Також тепловий стрес може призвести до зміни консистенції та кольору (становиться бліде) м'яса курятини, ознаки м'яса PSE. Відповідно температурний стрес може призвести до зменшення споживання корму, порушення травлення, порушення обміну речовин, зниження імунітету і навіть загибелі бройлерів. У цій статті узагальнено вплив холодного та теплового стресу на фрізіологію, продуктивність та якість м'яса бройлерів з метою поліпшення якості курятини, максимізації виробничих показників бройлерів, збільшення економічного зиску господарств та надання теоретичних рекомендацій щодо вирощування здорових бройлерів.

Ключові слова: бройлер; температура навколишнього середовища; фрізіологія; продуктивність; якість м'яса.

Дата надходження до редакції: 22.03.2019 p. 